\title{
Multiple Board Appointments and Firm Performance in Emerging Economies: Evidence from India*
}

\author{
Jayati Sarkar and Subrata Sarkar \\ Indira Gandhi Institute of Development Research
}

Working Paper Series No. WP-2005-001

January 2005

\begin{abstract}
The relation between multiple directorships, busy directors and firm performance has been researched predominantly in the context of developed economies, notably the US. This paper extends the existing literature on multiple directorships in two ways; first, by providing additional evidence on its effect on firm performance, but with respect to an emerging economy, India, and secondly, by suggesting an alternative measure of directorial "busyness" that is more general in its applicability compared to those that have been applied in the existing literature. Using a sample of 500 large firms from the Indian corporate sector for the year 2002-03, the paper finds multiple directorships by independent directors to correlate positively with firm value thereby supporting the "quality hypothesis" that busy directors are likely to be better directors, a result that is different from the existing evidence on busy directors. Multiple directorships by insider directors are, however, negatively related to firm performance. Estimation of group and non-group companies separately reveals that the quality effect of independent directors persists for the former but disappears for the latter. In general, the results suggest that the relation between "busy" directors and firm performance may depend on the institutional context and on the type of director.
\end{abstract}

Keywords: Multiple Directorships, Busy Directors, Firm Performance

JEL Classification: G30, G39, K22

\footnotetext{
* Preliminary Draft: Not to be quoted, comments welcome.

We thank the participants at the Workshop on Law and Economics at IGIDR, September 2004 for their helpful comments and suggestions on an earlier version of this draft. We also thank B. K. Chandra Kiran, Tirthankar Choudhuri, Arijit Ghosh, Jayashree Saha, Ekta Selarka and S. Sangeetha for excellent assistance in preparing the dataset. The usual disclaimer applies.

Address for correspondence: IGIDR, Gen.A.K.Vaidya Marg, Goregaon (E), Mumbai 400065,

India. E-mail: jayati@igidr.ac.in, ssarkar@igidr.ac.in
} 


\section{Introduction}

The number of positions that directors can accept on company boards has been a contentious corporate governance issue in countries around the world. Consequently, reform initiatives have focused on the need to limit the number of positions that a director can accept on company boards. The argument for limiting such multiple directorships can be stated in terms of the "busyness hypothesis" (Ferris et al., 2003), which postulates that a substantial number of directorial appointments can make directors over-committed and thereby compromise on their ability to monitor company management effectively on behalf of the shareholders. Several countries, like India, Malaysia and South Korea, have factored in such concerns by formally imposing regulatory limits on the number of boards on which an individual director can serve. However, several others, including developed countries like the US and UK are still debating the pros and cons of imposing such mandatory limits. In the US while some shareholder advocacy groups like the Council of Institutional Investors (CII) have explicitly recommended imposing such limits, the regulator has left the determination of the extent to which a director can have multiple appointments largely to the discretion of the corporations.

While the costs associated with multiple directorships seem to be obvious, the existing theoretical literature also highlights potential benefits from such directorships. For one, given the presence of a well functioning market for outside directors, the number of multiple directorships can signal a director's reputational capital so that a director with multiple directorships may proxy for high director quality (Fama, 1980, Fama and Jensen, 1983). Thus, having directors on board with multiple directorships can lead to better monitoring and thereby positively impact company performance. Second, from a resource dependency perspective it is argued that directors with multiple appointments, by virtue of being more networked, can generate benefits by helping to bring in needed resources, suppliers and customers to a company (Pfeffer, 1972; Booth and Deli, 1995).

Given differing theoretical viewpoints on the impact of multiple directorships on corporate governance and performance, it is not surprising that empirical evidence on the effect of such directorships along with that on the "busyness hypothesis" is somewhat mixed. On the one hand, some studies have found that busyness of directors can have a statistically adverse effect on 
performance, lower the sensitivity of CEO turnover to performance, manifest in a positive market reaction following the departure of a busy director (Fich and Shivdasani, 2004), lead to excess remuneration of CEOs (Core et al., 1999; Shivdasani and Yermack, 1999), and increase the probability of committing accounting fraud (Beasley, 1996). On the other hand, however, there are studies which show that directors with multiple appointments can serve shareholder interests by positively impacting company performance (Miwa and Ramseyer, 2000), can benefit shareholders through offering them larger premiums in tender offers (Cotter et al., 1997), and can generate superior returns from acquisitions. Finally, selected evidence, also with respect to the US suggests that multiple directorships do not have any significant negative effect on company value, nor do such directorships lead to directors shirking their responsibilities to serve on board committees or are associated with greater likelihood of securities fraud litigation (Ferris et al., 2003).

The objective of this paper is to extend the existing literature on multiple directorships in two ways. First, this paper seeks to provide additional evidence on the "Busyness Hypothesis," but based on evidence from an emerging economy, India. Secondly, the paper seeks to contribute to the relevant literature by suggesting an alternative measure of busyness that is more general in its applicability compared to those that have been applied in the existing literature.

With regard to the first objective, the reasons for choosing an emerging economy to analyze the busyness hypothesis are the following. One, we believe that an emerging economy like India form a more appropriate laboratory for analyzing the impact of multiple directorships on corporate performance. In contrast to the scenario in the US or other developed countries where there is a relatively long history of institutional investor organizations actively seeking to influence corporate governance policies of individual companies by publishing codes and best practices, such influences have been relatively uncommon in developing and emerging economies. It can thus be reasonably expected that the possibility of endogenizing (with a downward bias) the level of busyness of directors where company boards may need to consciously employ less busy directors in order to positively signal the market, is unlikely to be strong in such countries. While in some of these countries, mandatory limits have been placed on the number of directorships that can be accepted, such limits have been set at levels as high as ranging between ten (Malaysia) and twenty (India). The presence of such high limits, make such limits largely non-binding for many 
companies, yet keeps them free to hire directors with significantly high number of multiple directorships. This automatically is reflected in a higher average level of busyness as well as a greater variation in the extent of busyness of directors, and hence an ideal setting for analyzing the impact of multiple directorships on the effectiveness of monitoring in a cross-section of companies. Basic analysis of Indian data and a comparison with corresponding US data show that the mean number of directorships per director in India is at least as much as that obtained in US studies, but with the variation of busyness seemingly being more in the Indian context. ${ }^{1}$

An additional motivation for analyzing the impact of multiple directorships with respect to an emerging economy is that there is very little empirical evidence with respect to such countries that would help policy makers evolve best practices that are in consonance with the institutional context. It also provides one with an opportunity to examine the extent to which the impact of multiple directorships on company performance is institution-specific. The possibility that best practices on multiple directorships may be sensitive to the institutional context arises from our observation that the limits on such directorships that are in place in several of the emerging economies are significantly higher than the best practices that are in vogue in many of the developed countries (Table 1). While in the US, less than three multiple directorships is often considered best practice so much so that many of the empirical studies with respect to US define a busy director as one holding three of more directorships, the suggested or existing limit on multiple directorships in countries like India, Malaysia and Pakistan are much higher, between ten and twenty, with several exclusions permitted. Additionally, the limits set for executive or whole-time directors are sometimes significantly liberal compared to best practices adhered to in developed countries; in India, for instance, a whole time director can hold additional directorships in ten companies as compared to the suggested best practice limit in the Combined Code in UK whereby an executive director is recommended to not sit in more than one other board of a large listed company.

\footnotetext{
${ }^{1}$ While mean busyness of outside directors for US companies stand approximately between 1.6 (Ferris et al. 2003) and 3 (Fich and Shivdasani, 2004), with corresponding estimates of the percentage of busy directors ranging from as low as 14.97 per cent to 52 per cent, the estimates of mean busyness and percentage of busy directors for companies belonging to the top 500 in India stands around 4 and 57 per cent respectively. More importantly, compared to the US sample for which estimates are available, the variation of busyness as well as its range, are significantly more in India. While estimates with regard to US suggests that while only 0.33 per cent of directors in the sample have 6 board seats or more, the corresponding estimates for the top Indian companies is as high as 25 per cent.
} 
One explanation for such differences could be that the higher permissible limits on multiple directorships are driven by supply constraints in managerial labor markets characteristic of many developing countries, and in fact would negatively impact corporate performance. An alternative or complementary hypothesis could be that institutional specificities of these countries make it possible for a larger number of multiple directorships to be sustained without impairing the quality of corporate governance and performance and best practices in developed countries in this regard would be unnecessarily stringent. One can argue, normalizing for quality, that the demands of the job of a director, i.e., the nature of tasks that a director is required to perform on company boards, could be much less in a developing and emerging economies as compared to that in developed countries. In developed economies like the US where companies are much bigger in size and many of them have complex operations cutting across nations, the demands of the job may be very high. Accordingly, even three directorships may make a director over committed notwithstanding their ability. In contrast, in emerging economies like India, where companies are much smaller and relatively few of them are transnational in nature, the level at which over-commitment sets in may be much higher. This would be all the more so given the possibility that multiple directorships in developing economies where business groups typically dominate the corporate landscape, could be largely group specific, i.e., emanate mostly from within a particular group and thereby create synergies between different directorial responsibilities, both for executive and outside directors.

The second aspect in which this paper seeks to contribute to the literature is with respect to the important issue of how busyness associated with multiple directorships is measured in the first place. As Fich and Shivdasani (2004) purposefully argue, inferences regarding the effect of multiple directorships on firm performance could be sensitive to how busy directors are identified, and what in particular constitutes busy boards. A common feature of many of the existing studies (see for example, Core et al., 1999; Ferris et al., 2003; Fich and Shivdasani, 2004;) is that a busy director is defined exogenously as one who holds three or more directorships. The rationale for this definition seems to be derived from the "rule of thumb" limit on multiple directorships proposed by the Council of Institutional Investors in the US. Using this definition, the conclusions arrived by Ferris et al (2003) and Fich and Shivdasani (2004) are at odds, with the former finding no systematic relationship between firm performance and the extent of busyness, and the latter finding 
a statistically significant negative relationship between busy boards and firm performance. According to Fich and Shivdasani (2004), the differences in these results have stemmed from the differences in the "metric of busyness" that the respective studies have employed. For instance, in estimating the relationship between multiple directorships and firm performance, Ferris et al. (2003) proxy the business of the board by the average number of board seats held by outside directors. However, as Fich and Shivdasani (2004) illustrate with several examples, the average number of directorships may not be a good measure in this context, because the board often contains only a few individuals with extremely high number of multiple directorships that influence the average. Thus while a board might appear busy based on average directorships, it may be the case that a majority of the directorships are not busy. To address this problem, Fich and Shivdasani (2004) identify a busy board as one in which at least 50 percent of the outside directors are busy, where a busy director is taken as one who holds three or more directorships. Using this metric, the study finds that a busy board correlates with lower market value of the firm.

In defining our measure of board busyness we conform to the idea of Fich and Shivdasani (2004) that a measure of board busyness should not be driven by extreme observations but should reflect the busyness of a majority of the directors on the board. However, at the same time we do not impose any a priori definition of busyness, and instead attempt to endogenously determine the level of where a busy board has a negative effect on performance. Our contention is that the impact of busyness on performance is not only sensitive to the metric of busyness defined at the board level, but to the definition of a busy director per se. Busyness of a director as measured by the number of multiple directorships can be considered as a threshold level of multiple directorships beyond which "excessive” directorial commitments impinge on the director's ability to effectively monitor. $^{2}$ In all of the existing studies, a rather conservative definition of a busy director, one having at least three multiple directorships, is assumed. However, as stated above, a review of proposed limits on multiple directorships across countries show that limits of as high as ten or twenty multiple directorships are in vogue as also ones as low as two or three. Even within the US, while CII has come up with a proposal of three, Calpers has kept the limit open while highlighting its concern on the effects of "too many" directorships. In view of this, one can therefore argue that

\footnotetext{
${ }^{2}$ Such a threshold concept is also implicit in titles like “Too Busy to Mind the Business.?”
} 
by exogenously imposing a measure of a busy director, an examination of whether a multiple directorship of three at all can be construed as busyness in the first place, is precluded.

While unarguably, a larger number of directorial appointments impinge on the ability to monitor, it is not clear at which level of the individual can we consider one to be "busy." Such a determination, we argue, is as critical to the results that one obtains as the metric of busyness one uses at the board level. While Fich and Shivdasani (2004) prove that a board with at least half of busy outside directors will negatively affect company performance, their results do not conclusively prove that such a negative relationship would not have been obtained had busyness been defined as directors holding two directorships with a busy board constituting of at least fifty per cent of such directors. In that case, should one consider directors holding as low as two directorships also too busy to be effective? Would this then not render the entire debate on busyness trivial? Additionally, a demonstration of a negative impact on busyness does not provide insights into whether "high levels" of busyness are driving the statistically significant results. If alternatively, one breaks the sample of busy directors into less busy and more busy categories $(3-7)$ and greater than 7 , provided of course the data exhibits enough variation in busyness, it is theoretically possible that the relationship between busyness and performance becomes statistically significant only beyond seven, and with a board which has a majority of such directors. In that case, the policy implications would be very different and would be at odds with the CII proposal. Else, if statistical significance holds for the entire range, then the findings of the study can be considered to independently corroborate the proposed limit rather than exogenously imposing the proposed limit on the analysis. In similar vein, had Ferris et al., (2003) lowered the bar on the definition of busyness defining directors with a larger number of multiple directorships as "busy", it is theoretically possible that a negative and significant relation could have been captured between busyness and firm performance even by keeping their metric of board busyness the same.

In keeping with the above ideas we use the median directorships by directors as the measure of board busyness in our regression. Using the median accomplishes two things. First, it ensures, by construction, that majority of the directors hold any specified value of multiple directorships. Second, since the median enters the regression as a variable, we are able to examine the incremental effect as a board gets busier. Our measure encompasses the "busy board" variable of 
Fich and Shivdasani (2004). According to our definition all boards where the median directorships is three or more are the "busy boards" of Fich and Shivdasani (2004). Having selected the median as the measure of board busyness, we then fit a spline or piecewise linear regression between firm performance and board busyness. We set alternative turning points or spline nodes and estimate several regressions. The node at which we observe the relation between firm performance and board busyness to turn negative can then be identified the level of multiple directorships that makes a board busy. Thus our methodology determines endogenously as to what constitutes a busy board. This flexibility is important because the level at which busy boards have a negative effect on performance is likely to be different for different institutional contexts. Indeed, as we shall see below, our empirical analysis indicates that observed multiple directorships in India seems to more an indication of directorial quality rather than directorial busyness.

Using a sample of 500 large Indian companies and applying the above methodology we find multiple directorships by independent directors to correlate positively with market-to-book ratio once such directorships cross a particular threshold. Below the threshold we do not find any significant relation between multiple directorships and market-to-book ratio. In contrast to the results for independent directors, we find multiple directorships by executive directors to correlate negatively with firm performance. These findings are robust to alternative measures of firm performance based on accounting indicators like return to assets and net value added to assets. When we allow the effect of multiple directorships of independent directors to differ between nongroup and group companies, we find the positive relation to persist for the non-group companies, but this effect disappears for the group companies. A part of our results support the view that multiple directorships by independent directors may be a proxy of director quality and hence have a positive effect with firm value. However, other parts of our results indicate that such directorships could, in certain contexts, be driven by control motives of family owned business groups that are prevalent in emerging economies. In either case, though, we are unable to detect any negative effect of multiple directorships by independent directors on firm value. In contrast, multiple directorships by executive directors are found to correlate almost always negatively with firm performance. 
The rest of the paper is organized as follows. Section 2 outlines the institutional context governing the evolution of multiple directorships in India. Section 3 contains a description of the sample and the data used in the analysis and documents the incidence of multiple directorships in large Indian companies. The empirical analysis is reported in Section 4 and Section 5 concludes the paper.

\section{Multiple Directorships in India: The Institutional Context}

The phenomenon of multiple directorships in India can be traced back to the early stages of corporate sector development in the country. As Mehta (1955) observes, multiple directorships evolved in India in the initial stages of its industrial development due to a combination of various factors, namely a dearth of industrial leadership with ample commercial and industrial experience to serve on a company's board of directors, and due to the institution of managing agents under the Managing Agency System, who floated new companies and sought to control the management of these companies by being on their boards. The extent of multiple directorships in the early years of industrialization is apparent from the fact that as of 1949-50, individual directors held as high as 50 directorships spread across a wide variety of industries. Specifically, in the cotton industry, 25 eminent industrialists held as many as 150 directorships among them and 10 industrialists held about 82 directorships among them (Mehta, 1955). As the Company Law Committee (the Bhabha Committee) observed in 1950 in the context of amending the extant Companies Act, 1913, while multiple directorships in the UK and US rarely exceeded ten and in fact two to three directorships was the common pattern, a holding of 15 to 20 directorships in India around that time was most common and a holding of 30 was not unusual (Kust, 1964). It is in the context of such pervasiveness of multiple directorships in India and the associated concentration of managerial power that the Bhabha Committee strongly recommended setting legal limits through the Companies Act, 1956 on the number of directorships a director can accept. The limit was set at a relatively high level of 20 along with provisions for excluding from this number the directorships of private companies, which are neither a subsidiary, nor a holding company of a public company, unlimited companies or non-profit associations. The proposed limit was considered to be "desirable" by the Committee in view of the "paucity of high-grade business ability in the country" at that time. 
The recommendation of the Bhabha Committee was incorporated in Section 275 of the Companies Act, 1956 and has been in effect till present. In addition to this provision, a separate provision applied to the managing agents till the time the Managing Agency System was in vogue, i.e., April 1970. Since managing agents essentially managed the day to day operations of the company similar to the responsibilities of a modern day CEO (or managing director), in order to ensure that the affairs of the company received due and proper attention, Section 332 of the Companies Act, 1956 prohibited, with effect from August $15^{\text {th }}, 1960$, any managing agent to hold office as a managing agent in more than 10 companies. After the discontinuation of the managing agency system, a comparable provision was made in the Company Law applying to managing directors of companies whereby a managing director was prohibited from holding more than 10 directorial positions.

Since the nineties, as India joined a growing number of developed and developing countries in reforming existing corporate governance practices, several proposals on reducing the limit on multiple directorships have been made. While the consensus in this regard among the different corporate governance committees and working groups set up through government and private initiatives has been to reduce the existing limit on multiple appointments to reflect the changes in the underlying institutional conditions as well as current best practices, there are differences in opinion on what this limit would be. Among the competing proposals doing the rounds currently are those made (i) by the Committee on Corporate Governance set up by the Confederation of Indian Industry in 1998 which recommends within the overall limit of 20, no more than ten directorships in listed companies, (ii) by the Study Group on Corporate Governance set up by the Department of Company Affairs (DCA) which recommended not more than two other directorships in listed companies for a managing director and not more than 10 directorships in listed companies for other directors, and finally (iii) the Concept Paper of the Draft Companies Bill with comprehensive proposals to overhaul the existing Companies Act, 1956 and drawn up by the DCA which recommends bringing down the overall limit on multiple directorships to 15 , while keeping unchanged the maximum limit of 10 for managing directors. It should be noted that the Listing Agreements of major stock exchanges in India, including that of the Bombay Stock Exchange and National Stock Exchange, do not have any explicit provisions regarding total number of directorships that listed companies should have. 


\section{The Sample, Data and Incidence of Multiple Directorships}

\subsection{The Sample and the Data}

The sample for our analysis consists of 500 top private sector companies listed in the Bombay Stock Exchange and covers the financial year 2003. These companies accounted for about 90 percent of market capitalization as on March 2003. Both domestic and foreign private sector companies are represented in the sample, with domestic companies further classified into those belonging to business groups (group-affiliated) and those which are non-affiliated (standalones). Of the 500 companies, sixty eight per cent (388) of the sample companies are group affiliated, and the rest are split almost equally between Indian standalones (84) and foreign companies (78).

The data for our analysis is sourced from the Prowess database created by the Center for Monitoring the Indian economy (CMIE). We utilize the corporate governance (CG) reports contained in this database to collate the details of board membership by directors. According to Clause 49 of the Listing Agreement that came into effect from February 2000, all listed companies in India are required to file a CG report disclosing the details of board functioning. This report contains among other things, (i) the name of each director and his/her type i.e. promoter, executive, non-executive affiliated, non-executive independent, nominee director of financial institutions, (ii) the number of directorships and committee memberships held by the director in other listed companies, (iii) the number of board meetings held by the company in the financial year and dates on which they were held, (iv) and the attendance record of each director at the board meetings and in particular at the Annual General Meeting (AGM). Companies are required to file the CG report every quarter so that four such reports are available for a typical financial year. However, since in our empirical analysis we are going to relate the busyness of directors to firm performance for the financial year 2003 we are careful to consider only those companies for which the CG reports are available for the quarter ending March 2003. Accordingly, to pick our sample we ranked the private sector companies in terms of their sales in 2003 and then selected the first 500 companies for which the CG report was available for the above-mentioned date.

In addition to the data on multiple directorships we need information on accounting indicators, equity ownership, stock market variables, and other firm characteristics for our analysis. These data 
were sourced from the Profit and Loss Accounts, Balance Sheet, and stock price details of the companies contained in the Prowess database.

\subsection{Incidence of Multiple Directorships}

\subsubsection{At the director level}

The distribution of directors according to the number of directorships held as reported in the CG reports is presented in Table 2a. There are 3,891 directors in our sample companies holding 17,115 directorial positions. As Table 2a reveals, multiple directorships are quite pervasive in India with 71.6 per cent of directors in our sample holding more one directorial position. If one adopts the benchmark of three directorships to define a busy director as has been done in the US studies, one can see from Table 2a that as many as 56 per cent of directors hold 3 or more directorial positions. Available estimates of distribution with regard to US based on a sample of 3190, though not strictly comparable, show that only 15 per cent of directors hold 3 or more board seats (Ferris et al., 2003). Further, as can be noted from Table 2a, notwithstanding the regulatory ceiling of 20 in India, there exists considerable variation in directorships across directors in the sample companies even within the limit, which makes it feasible to study the relation between varying degrees of busyness on company value.

As stated earlier, the number of directorships held by directors of the sample companies has been disclosed by the directors themselves in the corporate governance reports and include directorships held in companies outside the sample. This is in contrast to some studies where the incidence of multiple directorships is calculated from within the sample companies which is likely to give an under estimate of such incidence (for example, Ferris et al., 2003). This is a great strength of our data in which the main variable of interest, i.e. the number of multiple directorships, is not subject to measurement error as it would be if it were to be calculated within the sample.

Table $2 \mathrm{~b}$ highlights this point. If one were to calculate the incidence of multiple directorships from within the sample, then the 3,891 directors hold only 5,045 directorial positions. In this case, one may note that as high as 81 per cent of directors hold single positions (compared to 28.4 in Table 2a) and only half a percent of directors hold six or more positions (compared to 14 per cent in Table 2a). The other key point that comes out from comparing Tables $2 \mathrm{a}$ and $2 \mathrm{~b}$ is that since the 
number of directorships held within the sample companies is very low, one can conclude that while directors in large listed companies on the average have 4.4 directorial positions, most of these are held in smaller companies.

Table 3 presents summary statistics on multiple directorships, based on both reported and in-sample data. As can be seen from the Table, the mean directorships held per director as reported is greater than the median, implying that the distribution is skewed to the right. This means that that there are some directors holding large number of directorships, and exceeding the ceiling of 20. However, as stated earlier, there are several exclusionary clauses in the Company Law that allows directors to exceed the ceiling.

\subsubsection{At the board level}

How does the incidence of multiple directorships at the individual level translate into multiple directorships at the board level? Is the incidence of multiple directorships different between insider and outsider directors? How busy are the promoter directors who sit on company boards? To answer these questions we first need to look at the size and composition of a typical board of the sample companies that is given in Table 4 .

Comparable estimates available for a sample of US companies are also shown in the Table. As is evident from the Table, while mean board size is somewhat larger in the US compared to that in India, the proportion of inside directors is almost equal (26 and 25 per cent respectively). It is in the composition of non-executive directors that there exists some striking differences between the two countries; the percentage of gray directors in India is significantly higher at 20 per cent compared to 14 per cent for US companies. The other difference arises from the fact that a fair proportion of independent directors in India comprise of nominees of financial institutions like development banks and mutual funds who are not elected to the board by shareholders but are nominated by financial institutions to monitor the companies on their behalf.

Looking at board size and composition by ownership groups, one finds that there is some noticeable variation across these groups. Compared to the group-affiliated and foreign companies, standalone companies have smaller boards, possibly because they are smaller companies on the 
average, and have more inside directors than the overall average on their boards. With regard to the composition of non-executive directors, foreign companies have the highest proportion of such directors identified as gray or affiliated directors compared to the domestic companies. Among the domestic companies, the proportion of affiliated directors is understandably higher in group firms than that of standalones given that the former are often family controlled with the promoter or close relatives of the promoter having presence on company boards. Finally, the presence of nominee directors is the most in group affiliated firms possibly on account of the fact that the exposure of financial institutions to these companies is usually higher and at the same time the need for monitoring is higher owing to concerns such as diversion of funds to group affiliates through practices like tunneling.

Table 5 below shows for the directors of our sample companies, the proportion of busy directors by type across ownership groups for two levels of busyness. The first level, Busyness 1 shows the percentage of directors of different types holding three or more directorships. This measure corresponds to the measure of busyness that has been adopted as a standard for a busy director in existing studies. The second level of busyness, Busyness 2, is defined as the percentage of different types of directors holding six or more directorships, where six is the upper quartile in the distribution of directors according to the number of directorships.

As Table 5 shows, for the entire sample, around 52 per cent of executive directors (EDs) hold three or more directorships and around 22 per cent of such directors hold six or more directorships. With respect to the promoter executive directors (PEDs), both Busyness 1 and Busyness 2 are significantly higher than that of EDs (73.27 and 34.81 per cent respectively). With respect to nonexecutive (outside) directors (NEDs) too, it is the promoter non-executive directors (PNEDs) who are busier on the average than an independent non-executive director, for both the measures, Busyness 1 and Busyness 2. Several basic observations on multiple directorships in countries like India can be made from these estimates. First, busyness of a director is as much of an insider director phenomenon as an outside director phenomenon. Secondly, promoter directors are busier than professional (non-promoter) directors, both in the capacity of EDs and NEDs. Combining the busyness of directors of different types, Table 6 gives several measures of busyness of a typical board in a large Indian company. 


\section{Empirical Analysis}

\subsection{Empirical Methodology}

Our discussion at the beginning suggests that multiple directorships per se do not render a director "busy”. Directors with large number of multiple appointments may be better quality directors and hence more effective monitors. If such individuals dominate the board, then firm value might increase. However, even for better quality directors, additional directorships beyond a certain point will make them over-committed. If such individuals dominate the board then firm value might decrease. In either case, however, we do not know the threshold at which we can take multiple directorships to be a signal of quality or a signal of over commitment or "busyness". This suggests that the regression specification that we choose for our empirical analysis should be such that it allows the relation between busyness and firm performance to change at some level of busyness that is unknown to us. In keeping with this idea we felt that the spline formulation is an appropriate specification of our regression equation. Spline is a commonly used technique in empirical analysis to estimate a piecewise relation between two variables that allows the slope of the relation to change at specific points known as spline knots or spline nodes. The number of spline nodes and their specific values are to be determined from theory and/or data.

Our empirical analysis relates busyness to performance at the firm level. We therefore need a measure that translates the busyness of the directors from the individual level to busyness at the board level. One straightforward measure is the mean number of directorships held by the directors on the board as is used by Ferris et al. (2003) However, as Fich and Shivdasani (2004) note, and as our data supports, the mean is not an appropriate measure in this case, since the distribution of directorships is generally positively skewed so that a high mean is driven by the presence of one or two directors with a large number of multiple appointments whereas the rest may not be busy. In this case a better measure is the median that ensures that at least majority (i.e.. 50 percent) of the directors hold the specified number of directorships. In keeping with this idea we use the median value to proxy the busyness of the board. However, unlike Fich and Shivdasani (2004), we do not identify busy boards with those where 50 percent of the directors hold three or more directorships, i.e., the median is three or more. Rather we use the median as a variable in our regression. Thus in our analysis we essentially have a range of busy boards starting from one where more than 50 per cent of directors hold two or more directorships, followed by a busy board where more than 50 per 
cent hold three or more directorships and so on and then estimate the relationship between different levels of board busyness and company performance using the spline formulation.

In estimating the relation between busyness and firm performance we consider both executive directors as well as independent directors. Most studies with respect to the US focus on independent directors perhaps because multiple directorships by executive directors are not very common. However, as we have seen earlier, multiple directorships by insider directors in India is pervasive and calls for closer scrutiny. In specifying the regression, we make a distinction between executive directors and independent directors, because we believe that the factors that determine multiple directorships for these two groups are likely to be different as would be the effect on firm value. Executive directors are full time employees of the company and are entrusted with its day-today operation. Additional directorships even at low levels may make them over-committed and have negative effect on firm value. Also, the managerial market and the reputation argument that we have discussed earlier regarding multiple directorships are more likely to apply for the independent directors rather than the executive directors. This is particularly true in economies like India where the corporate sector is dominated by business group companies and where we have documented that promoters often sit on company boards as executive members. Their multiple directorships are likely to be driven more by institutional reasons rather than the managerial market story. For the same reasons, we exclude the affiliated non-executive directors and consider only the independent directors in the regression.

Finally, we control our regression for other factors that might affect company value. Important among these are corporate governance variables that have been documented in earlier studies to influence company value. We include log of board size, proportion of independent directors, share ownership by promoters, and share ownership by foreign institutional investors in the regression. In addition, since a company's current profitability might influence its market value, we include return on assets as a control variable. Return on assets is calculated as profit before interest and tax divided by total assets. Further, we introduce the ratio of R\&D expenditure to sales and the ratio of advertising expenditure to sales as proxies for company's growth opportunities. Finally, we control for firm size by introducing the log of total assets into the regression. Thus, the relation that we estimate takes the form: 
Company performance $=f$ (spline(executive directors), spline(independent directors), other corporate governance and control variables) + error

To begin with we use market-to- book ratio as a measure of company performance. We calculate market-to-book ratio by multiplying the number of shares outstanding at the end of the year by the mean of the closing prices observed on each trading day of the year, and dividing it by the book value of equity at the end of the year. Later we re-estimate our regression with Tobin's-Q, an alternative measure of a company's market performance, and well as return to assets and net-valueadded to assets, both of which are measures of a company's operating performance.

\subsection{Empirical Findings}

Table 7 reports the results of the market-to-book regression where we have adopted a linear specification for the median directorships of independent directors and executive directors. This can be looked as a special case of the spline formulation where the spline node is set at the lowest values of the corresponding variables in the sample. The linear specification is of interest because if the quality effect is very strong or the negative effect of busyness sets in at very low levels of multiple directorships, then we expect the linear specification to capture this. From Table 7 we observe that the coefficient of median directorships by independent directors is positive but not significant at the usual levels of significance. Its p-value is 0.23 . In contrast, the coefficient of median directorships by executive directors is negative and highly significant with a p-value of 0.02. Thus our initial market-to-book regression detects a strong negative effect of busyness of executive directors but does not detect any negative effect of busyness of independent directors. If at all, the effect for the latter appears to be weakly positive suggesting that the quality argument may be at work.

We investigate our initial results further by estimating the market-to-book regression using the spline formulation. We choose only one spline node for both multiple directorships by independent directors and executive directors because this seems to be the obvious specification given our discussion above. Since we have one spline node, there are two spline variables, spline1 and spline2, for each type of multiple directorships. Suppose we set the node to three with respect to 
median directorships by independent directors. Then the coefficient on the spline1 variable shows the relation between multiple directorships and company performance up to the point where majority of the independent directors on the board hold less than three directorships, while the coefficient on the spline2 variable shows the relation between company performance and multiple directorships from the point where majority of the independent directors hold three or more directorships. If we exogenously define the median of three as the level which constitute busy boards, then spline2 shows the relation between company performance and busy boards as is envisaged in Fich and Shivdasani (2004), except that their analysis uses a dummy variable formulation while the spline specification implies a linear relation. When we allow the spline node to change, we allow the threshold that constitutes busy boards, to change. In this way, the spline specification is a more flexible formulation.

Table 8 reports the results of the spline regressions for different nodes starting with three. With respect to multiple directorships by independent directors we observe that for nodes equal to three the coefficients on both the spline variables, spline1 and spline2, are statistically insignificant with very high p-values of 0.77 and 0.36 respectively. Thus, if we use the median of three to define busy boards, we are unable to uncover any effect of busy boards on company performance. When we set the spline node to four, we reach the same conclusion with the p-values being 0.84 and 0.22 respectively. However, when we set the node to five we observe that while the coefficient of the spline1 variable remains to statistically insignificant (p-value 0.32), the co-efficient on the spline2 variable is positive and highly significant with a p-value of 0.0552 . When we change the node to six, the p-value on the spline 1 co-efficient is 0.23 while that on the spline 2 coefficient is 0.02 . This insignificance of the spline1 variable and the positive and significant coefficient on the spline 2 variable remains robust as we change the spline nodes to values beyond six and up to ten for which there is some minimum number of observations to meaningfully estimate the effect of the spline2 variable, though, for brevity, we report the results for nodes up to eight in the table. Thus, with our spline specification we do not find any negative relation between busyness of independent directors and company performance. Rather we find a strong positive relation once busyness crosses a particular threshold. This finding tends to support the view that multiple directorships can be reflection of the quality of independent directors where the more able directors are successful in 
attracting more directorships. This interpretation seems particularly probable because we have uncovered the positive relation to hold only above a certain level of multiple directorships.

In sharp contrast to the results for independent directors, the co-efficient on the spline1 variable for the executive directors is negative and highly significant while the co-efficient on the spline2 variable remains insignificant in all the regressions displayed in Table 8. For example for node equal to three, the p-value for the spline 1 variable is 0.03 (with a coefficient estimate of -0.17) while the p-value for the spline2 variable is 0.47 . Similarly for node equal to four the p-value for the spline1 variable is 0.02 (with a co-efficient estimate of -0.12) while the p-value for the spline2 variable is 0.83 . The regression results suggest that the implications of multiple directorships by executive directors are very different from those by independent directors. Multiple directorships by executive directors seem consistent with the busyness hypothesis with even low levels of multiple directorships correlating negatively with company value. The insignificance of the spline2 variables is consistent with the argument that the effect of even low levels of multiple directorships is so strong that additional directorships beyond those levels do not have any further negative effect on company value.

The coefficients of most of the control variables are along expected lines. We find a positive and statistically significant relation between promoters' share and market-to-book ratio which is consistent with the findings by earlier studies that ownership tends to correlate positively with company value once it crosses a particular thresholds (Morck et al. (1988), McConnell and Servaes (1990), Sarkar and Sarkar (2000)). In our sample, the mean promoters' holding is as high as 53.58 percent. We also find shareholdings by foreign institutional investors to be positively and significantly correlated with company performance. A company's current profitability has a positive and significant association with its market value. Advertising intensity is positively and significantly related to market-to-book ratio, while R\&D expenditure is not significant at the usual levels of significance. Since both these variables are taken as proxies for a firms' investment opportunities, R\&D expenditure does not seem to add any extra information beyond that contained in advertising expenditure. The co-efficient of firm size is positive in all regressions though it attends significance only at the 15 percent level. However, coefficients of two variables related to board characteristics offer some contrast to earlier studies. First, unlike Yermack (1996), we do not 
find board size to have any significant relation with company value and second we, find the proportion of independent directors to correlate negatively with company value.

\subsection{Robustness Checks}

Our results above are obtained using market-to-book ratio as the measure of firm's market performance. This is a clean and well-understood measure by investors. Many studies use Tobin's$\mathrm{Q}$ as an alternative measure of a firm's market performance. Tobin's-Q is defined as the ratio of market value of equity and debt divided by the replacement cost of assets. We try to verify our results using Tobin's-Q as the dependent variable. Since in India a large part of debt is institutional debt which is not traded in the capital market and companies report value of their assets at historical costs, we proxy Tobin's-Q with the market value of equity plus the book value of debt divided by the book value of assets. Both market-to-book ratio and Tobin's-Q are influenced by a company's growth opportunities. Our regressions control for this effect through the inclusion of advertising expenditure and R\&D expenditure as explanatory variables. However as both Yermack (1996) and Fich and Shivdasani (2004) note, such controls may be imperfect and can confound the statistical inferences regarding the effect of multiple directorships. Therefore, it is instructive to verify our regressions using accounting measures that are unlikely to be driven by a firm's investment opportunities. We use two accounting measures namely return on assets and net-valueadded to assets. We calculate return to assets by dividing earnings before interest and tax by total assets. In each of these regressions we set the spline node for independent directors to five as it is at this node that spline2 variable first becomes significant, but enter the median directorships of executive directors in a linear fashion because our earlier results indicate a strong negative effect from very low levels of multiple directorships for these directors.

Columns A, B, and C of Table 9 reports the results of the regressions with Tobin's-Q, return-onassets, and net-value-added to assets, respectively. In all of these regressions, the coefficient of the spline1 variable for independent directors continues to be insignificant, while the co-efficient on the spline2 is significant in the two regressions involving the accounting indicators (p-values of 0.01 and 0.0). However, in the regression involving the Tobin's-Q, the co-efficient though positive, is not significant at the usual levels (p-value 0.18). With respect to executive directors, the coefficient of median directorships is negative and significant (p-value of 0.01) in the regression with Tobin’s- 
Q. However, in the regression with return-on-assets the co-efficient is insignificant (p-value 0.23) while in the net-value-added to assets regression the coefficient is negative and significant at the 10 percent level. Thus our additional regressions, in general tend to support the quality argument advanced for independent directors. However, with respect to the executive directors while our earlier conclusion regarding the negative association between market indicators and multiple directorships is further strengthened, this conclusion is somewhat weakened when we use accounting indicators. One possible explanation of this result could be that while firms with busy executive directors do not experience any deterioration in their short-term performance, the market expects such deterioration to eventually occur in the future.

\subsection{Difference between Group and Non-group Companies}

Till now our results have been obtained by treating group companies symmetrically with standalone and foreign companies. However, multiple directorships in group companies raises an additional important question namely that of appointing a same individual on the boards of multiple companies within the same group. Such appointments need not be value reducing. Directors who work on boards of multiple member companies may be able to co-ordinate the aims of the group in a better way. Group companies are often vertically integrated and knowledge about future projects of upstream and downstream companies can be highly valuable for directors in evaluating strategic planning of companies on which they act as board members. However, multiple directorships in group companies may also be a way by promoters of rewarding directors who have been loyal to them in the past or indeed the initial appointment itself could be based on loyalty so as to minimize the chance of losing control over the group in case of conflicts among owners. Anecdotal evidence in India abounds of such family conflicts and instances of the same person being on boards of multiple companies in the group. In the later case, multiple directorships are not driven by market conditions and its effect on company value could go either way.

In order to address this important issue we interact the two spline variables spline1 and spline2 based on median directorships by independent directors with a dummy variable called "group” which equals one when the company is an affiliated to a business group and zero otherwise. The coefficient on the variable "spline1 * group" then gives the difference in effect between group companies and non-group companies (foreign and standalone companies) of multiple directorships 
below a threshold level, while the coefficient of the variable "spline2 * group" gives this difference above the threshold level. We set the threshold level to five and introduce the median directorships by executive directors in the linear fashion based on the logic outlined earlier.

Columns A, B, C, D, of Table 10 reports the results of this regression based on the four alternative measures of company performance, namely MBVR, Q-Ratio, return to assets, and net value added to assets. In each of these four regressions the coefficient of the two spline variables namely spline1 and spline2 are qualitatively as same as before. The coefficient on the spline1 variable is never significant while the coefficient on the spline2 variable is positive and highly significant. However, these coefficients are now applicable only to standalone companies and foreign companies. For group companies, we need to refer to the coefficients of the interaction terms. We observe that in each of these four regressions the coefficient of the first interaction term is negative but attends significance only in the net value added regression. In contrast, the coefficient on the second interaction variable is negative and significant in the first three regressions, while in the net value added regression it is negative but not significant at the conventional levels. Thus, our results suggest that there is a remarkable difference in the effect of multiple directorships between group and non-group companies. Compared to non-group companies, the effect of multiple directorships above the threshold is significantly lower for the group companies. The total effect of for group companies of course is the sum of the coefficient of the spline variable and the coefficient of the corresponding interaction variable. The coefficients associated with "spline2" and "spline2 * group” are opposite in sign but similar in magnitude in the first three regressions suggesting that the total effect is small. A Wald test on the null hypothesis that the sum of these coefficients is equal to zero fails to reject the null hypothesis even at the 10 percent level. Thus our regressions suggest that the quality hypothesis that we had advanced earlier is applicable largely to the non-group companies. For group companies this conclusion is supported by only one of the four regressions i.e., net value added to assets regression, while the remaining three regressions indicate no such positive effect. However, a point to note is that even for group companies our regressions fail to detect any negative effect of multiple directorships by independent directors. 


\section{Conclusions}

In this paper we have examined the effect of multiple directorships on company performance in an emerging economy. Our regressions support that idea that busyness may sometimes proxy for director quality. The fact that we have been unable to detect any negative effect of busyness in our sample even when a significant proportion of independent directors hold directorships much in excess of three directorships should not come as a surprise. As we have outlined in the beginning, the level beyond which multiple directorships have a negative effect on company performance is dependent on two things. First the demands of the job i.e., the nature of tasks directors are required to perform on company boards, which in turn depends on the characteristics of the company, and two, the ability of the directors. In the US where companies are much bigger in size and many of them have complex operations cutting across nations, the demands of the job may be very high. Accordingly, even three directorships may make a director over-committed notwithstanding their ability. In contrast, in countries like India, where companies are much smaller and relatively few of them are transnational in nature, the level at which over commitment sets in may be much higher. In the same spirit, the effect of multiple directorships by executive directors may be different than that by independent directors, because the demands of the formers' job are different. Finally, our analysis suggests that there is a difference between group and non-group companies. The quality argument does not seem to hold for busy directors of group companies. Multiple directorships in group companies may be driven by more complex reasons. One possibility that we have outlined is that promoters may appoint same directors on the boards of member firms. This can force these directors to align their interests with that of the promoters as doing otherwise may be costly. Unfortunately we are unable to verify this because our current sample is inadequate to track all the companies in which independent directors hold their directorships. But this is an interesting area of work that we plan to investigate in the future. 


\section{References}

Beasley, Mark, 1996, An empirical analysis of the relation between board of director composition and financial statement fraud, The Accounting Review 71, 443-465.

Bhagat, Sanjai and Bernard Black, 2002, The Non-Correlation between Board Independence and Long-Term Firm Performance, The Journal of Corporation Law, 27, 231-273.

Booth, James and Daniel Deli, 1995, Factors affecting the number of outside directors held by CEOs, Journal of Financial Economics, 40, 81-104.

Core, James Robert Holthausen and David Larcker, 1999, Corporate governance, chief executive officer compensation, and firm performance, Journal of Financial Economics 51, 371-406.

Cotter, James, Anil Shivdasani and Marc Zenner, 1997, Do independent directors enhance target shareholder wealth during tender offers? Journal of Financial Economics 43, 195-218.

European Corporate Governance Institute, Codes and Principles, http://www.ecgi.org/codes/index.php

Fama, Eugene, 1980, Agency Problems and the Theory of the Firm, Journal of Political Economy, 88, 288-307.

Fama, Eugene and Michael Jensen, 1983, Separation of ownership and control, Journal of Law and Economics 26, 301-326.

Ferris, Stephen, Murali Jagannathan and A. C. Pritchard, 2003, Too busy to mind business? Monitoring by Directors with Multiple Board Appointments, Journal of Finance, LVIII 3, 1087-1111.

Fich, Eliezer and Anil Shivdasani, 2004, Are busy boards effective monitors?, Working Paper, Kenan-Flagler Business School, University of North Carolina.

Kust, Mathew, 1964, Foreign enterprises in India: Laws and Policies, Chapel Hill: The University of North Carolina Press.

McConnell, John and Henri Servaes, 1990, Additional evidence on equity ownership and corporate value, Journal of Financial Economics, 27, 595-612.

Mehta, M. M., 1955, The structure of Indian industries, Bombay, Popular Book Depot.

Miwa, Yoshiro, and J. Mark Ramseyer, 2000, Corporate governance in transitional economies: Lessons from the pre-war Japanese cotton textile industry, Journal of Legal Studies 29, 171204.

Morck, Randall, Andrei Shleifer and Robert W. Vishny, 1988, Management ownership and market 
valuation: An empirical analysis, Journal of Financial Economics, 20, 293-315.

Organisation for Economic Co-operation and Development, 2003, White Paper on Corporate Governance in Asia. www.oecd.org/dataoecd/4/12/2956774.pdf

Pfeffer, J. ,1972, Interorganizational influence and managerial attitudes, Academy of Management Journal, 15, 317-330.

Sarkar, Jayati and Subrata Sarkar, 2000, Large Shareholder Activism in Corporate Governance in Developing Countries: Evidence from India, International Review of Finance, Vol. 1, No.3, 161-194.

Shivdasani, Anil and David Yermack, 1999, CEO involvement in the selection of new board members: An empirical analysis, Journal of Finance 54, 1829-1853.

Yermack, David, 1996, A higher market valuation of companies with a small board of directors, Journal of Financial Economics 40, 185-205. 
Table 1: Multiple Directorships: Limits on Directorial Positions

\begin{tabular}{|c|c|}
\hline China & None \\
\hline India & $\begin{array}{l}\text { Yes; Not more than } 10 \text { for managing director; Not more than } 20 \\
\text { for others; exclusions; penalties for violation; Recommended : } \\
\text { Not more than } 15 \text { (maximum } 10 \text { listed companies), } 1+2 \text { for } \\
\text { managing director. }\end{array}$ \\
\hline Indonesia & None \\
\hline Malaysia & Yes; 10 listed companies; 15 otherwise. \\
\hline Pakistan & Yes; Maximum 10. \\
\hline Philippines & None \\
\hline Singapore & None \\
\hline South Korea & Yes; Maximum 2 for non-executive directors \\
\hline Thailand & None; except for bank directors; maximum 5 . \\
\hline UK & $\begin{array}{l}\text { None; executive director recommended to not sit in more than one } \\
\text { other board of a large listed company. }\end{array}$ \\
\hline USA & $\begin{array}{l}\text { None; No limit: Recommended: not more than } 2 \text { (CII Core } \\
\text { Principles) }\end{array}$ \\
\hline
\end{tabular}

Source: White Paper on Corporate Governance in Asia, (OECD 2003);

Codes and Principles, European Corporate Governance Institute, http://www.ecgi.org/codes/index.php 
Table 2a: Distribution of Directors in Terms of Directorships Held As Reported in the Corporate Governance Report

\begin{tabular}{rrrrr}
\hline $\begin{array}{l}\text { No. of } \\
\text { directorships }\end{array}$ & Frequency & Percent & $\begin{array}{c}\text { Cumulative } \\
\text { Frequency }\end{array}$ & $\begin{array}{c}\text { Cumulative } \\
\text { Percent }\end{array}$ \\
\hline 1 & 1104 & 28.37 & 1104 & 28.37 \\
2 & 613 & 15.75 & 1717 & 44.13 \\
3 & 454 & 11.67 & 2171 & 55.80 \\
4 & 349 & 8.97 & 2520 & 64.76 \\
5 & 238 & 6.12 & 2758 & 70.88 \\
6 & 233 & 5.99 & 2991 & 76.87 \\
7 & 167 & 4.29 & 3158 & 81.16 \\
8 & 148 & 3.80 & 3306 & 84.97 \\
9 & 123 & 3.16 & 3429 & 88.13 \\
10 & 103 & 2.65 & 3532 & 90.77 \\
11 & 80 & 2.06 & 3612 & 92.83 \\
12 & 64 & 1.64 & 3676 & 94.47 \\
13 & 61 & 1.57 & 3737 & 96.04 \\
14 & 55 & 1.41 & 3792 & 97.46 \\
15 & 40 & 1.03 & 3832 & 98.48 \\
$16+$ & 52 & 1.52 & 3891 & 100.00 \\
& & & & \\
\hline
\end{tabular}

Table 2b: Distribution of Directors in Terms of Directorships Held In the 500 Sample Companies

\begin{tabular}{rrrrr}
\hline $\begin{array}{l}\text { No. of } \\
\text { directorships }\end{array}$ & Frequency & Percent & $\begin{array}{c}\text { Cumulative } \\
\text { Frequency }\end{array}$ & $\begin{array}{c}\text { Cumulative } \\
\text { Percent }\end{array}$ \\
\hline 1 & 3174 & 81.57 & 3174 & 81.57 \\
2 & 474 & 12.18 & 3648 & 93.75 \\
3 & 136 & 3.50 & 3784 & 97.25 \\
4 & 57 & 1.46 & 3841 & 98.71 \\
5 & 30 & 0.77 & 3871 & 99.49 \\
$6+$ & 20 & 0.51 & 3891 & 100.00 \\
\hline
\end{tabular}


Table 3: Summary Statistics of "Busyness" in India

\begin{tabular}{lcc}
\hline & $\begin{array}{c}\text { As Reported in } \\
\text { The CG Report }\end{array}$ & $\begin{array}{l}\text { In the 500 sample } \\
\text { Companies }\end{array}$ \\
\hline Total No. Of Directors & 3891 & 3891 \\
Total Directorships & 17115 & 5045 \\
Min & 1 & 1 \\
Lower quartile & 1 & 1 \\
Median & 3 & 1 \\
Mean & 4.4 & 1.3 \\
Upper quartile & 6 & 1 \\
Upper decile & 10 & 2 \\
Max & 53 & 14 \\
\hline
\end{tabular}

Table 4: Board Size and Board Composition for a Sample of 500 Large Companies in India and US

\begin{tabular}{llllll}
\hline Means of Variables & $\begin{array}{l}\text { Group- } \\
\text { affiliated }\end{array}$ & $\begin{array}{l}\text { Stand- } \\
\text { alone }\end{array}$ & Foreign & All & US $^{1}$ \\
\hline Board Size (number) & 9.78 & 8.49 & 9.14 & 9.46 & 11.45 \\
\hline Percentage of Executive & 23.73 & 33.17 & 24.11 & 25.38 & 26 \\
directors & 17.91 & 20.67 & 22.63 & 19.11 & $\mathrm{n} . \mathrm{a}$. \\
- Executive directors & 5.82 & 12.50 & 1.48 & 6.27 & $\mathrm{n} . \mathrm{a}$. \\
- Promoter-executive & & & & & \\
$\quad$ directors & & & & & \\
\hline Percentage of Non-executive & 76.27 & 66.83 & 75.89 & 74.62 & 74 \\
directors & 19.56 & 14.27 & 31.03 & 20.46 & 14 \\
- Affiliated & 5.55 & 6.16 & 6.37 & 5.78 & $\mathrm{n} . \mathrm{a}$. \\
$\quad-$ Promoter - non- & 56.71 & 52.56 & 44.86 & 54.16 & 60 \\
$\quad$ executive & 9.18 & 4.17 & 2.56 & 7.30 & $\mathrm{n} . \mathrm{a}$ \\
- Independent & 47.53 & 48.39 & 42.30 & 46.86 & $\mathrm{n} . \mathrm{a}$ \\
$\quad-$ Nominee & & & & & \\
$\quad-$ Non-nominee & & & & & \\
\hline
\end{tabular}

1 (Bhagat and Black, 2002) 934 large US companies, 1991; n.a.: not available Data for India: Authors' estimation based on Corporate Governance Reports of $50 \odot$ top Indian companies, 2003 


\section{Table 5: "Busy" Directors by Type}

\begin{tabular}{lcccc}
\hline $\begin{array}{l}\text { Type of } \\
\text { Director }\end{array}$ & $\begin{array}{l}\text { Business } \\
\text { Group }\end{array}$ & $\begin{array}{l}\text { Stand-alone } \\
\text { Companies }\end{array}$ & $\begin{array}{l}\text { Foreign } \\
\text { Companies }\end{array}$ & $\begin{array}{l}\text { All } \\
\text { Companies }\end{array}$ \\
\hline & & & & \\
ed & 58.61 & 39.49 & 40.66 & 52.65 \\
& $(28.23$ & 8.11 & 11.39 & $22.31)$ \\
ped & 78.52 & 57.46 & 80.00 & 73.27 \\
& $(43.90$ & 11.75 & 16.00 & $34.81)$ \\
ned & 71.33 & 42.22 & 45.45 & 62.79 \\
& $(43.37$ & 13.33 & 23.29 & $35.91)$ \\
pned & 83.79 & 37.88 & 58.99 & 73.43 \\
& $(53.95$ & 8.33 & 23.99 & $43.09)$ \\
nedi & 66.32 & 51.37 & 70.48 & 64.45 \\
& $(33.73$ & 21.11 & 41.69 & $32.86)$ \\
nominee & 51.87 & 39.02 & 56.82 & 50.53 \\
& $(9.42$ & 11.36 & 9.09 & $9.65)$ \\
\hline
\end{tabular}

Notes:

The table gives the proportion of busy directors within each group. Two measures of "busy" directors are used. Measure 1: A director holding three or more directorships (Roman numbers) Measure 2: A director holding seven or more directorships (Italics numbers) 
Table 6: "Busyness" of a Typical Board in India

\begin{tabular}{lcccc}
\hline & $\begin{array}{l}\text { Business } \\
\text { Group } \\
\text { Companies }\end{array}$ & $\begin{array}{l}\text { Stand-alone } \\
\text { Companies }\end{array}$ & $\begin{array}{l}\text { Foreign } \\
\text { Companies }\end{array}$ & $\begin{array}{l}\text { All } \\
\text { Companies }\end{array}$ \\
\hline $\begin{array}{l}\text { Mean directorship } \\
\text { per director }\end{array}$ & 5.49 & 3.60 & 4.80 & 5.06 \\
$\begin{array}{l}\text { Median directorship } \\
\text { per director }\end{array}$ & 4.85 & 2.94 & 3.24 & 4.28 \\
$\begin{array}{l}\text { Max. directorship } \\
\text { by a director on } \\
\text { the board }\end{array}$ & 11.94 & 8.81 & 13.10 & 11.60 \\
$\begin{array}{l}\text { Percentage of busy } \\
\text { Directors } \\
\text { (busy }=\end{array}$ & 67.04 & 47.17 & 53.13 & 61.53 \\
$3+$ directorships) & & & & \\
\hline
\end{tabular}


Table 7: Regression of Market to Book Ratio on Busyness, Board Structure, and Other firm Characteristics - Linear Specification of Busyness

\begin{tabular}{lccc}
\hline Variable & Parameter Estimate & t- Value & $\begin{array}{c}P \text {-Value } \\
\text { Pr }|t|\end{array}$ \\
\hline Intercept & -0.15823 & -0.30 & 0.7623 \\
tldirsp_ind1_med & 0.01956 & 1.21 & 0.2280 \\
tldirsp_ins_med & -0.03243 & -2.27 & 0.0237 \\
boardsize & 0.06492 & 0.37 & 0.7139 \\
pind_dir_1 & -0.00512 & -1.84 & 0.0659 \\
pro_s & 0.00752 & 2.67 & 0.0079 \\
fii_s & 0.05813 & 5.17 & $<.0001$ \\
ret_as1 & 0.01864 & 3.03 & 0.0025 \\
Rdint & 0.06054 & 1.26 & 0.2076 \\
Advint & 0.07783 & 5.04 & $<.0001$ \\
Size & 0.06925 & 1.26 & 0.2080 \\
Industry Dummy & Yes & & \\
R-Sqaured & 0.2918 & & \\
\hline
\end{tabular}


Table 8: Regression of Market to Book Ratio on Busyness, Board Structure, and Other

Firm Characteristics

- Spline Specification of Busyness

\begin{tabular}{|c|c|c|c|c|c|c|c|c|c|c|c|c|}
\hline \multirow[t]{2}{*}{ Spline Node } & \multicolumn{2}{|l|}{3} & \multicolumn{2}{|l|}{4} & \multicolumn{2}{|c|}{5} & \multicolumn{2}{|c|}{6} & \multicolumn{2}{|c|}{7} & \multicolumn{2}{|c|}{8} \\
\hline & Estimate & P-value & Estimate & P-value & Estimate & P-value & Estimate & P-value & Estimate & P-value & Estimate & P-value \\
\hline Intercept & 0.02680 & 0.9616 & 0.01071 & 0.9840 & -0.00388 & 0.9941 & -0.03359 & 0.9487 & -0.06502 & 0.9006 & -0.09902 & 0.8491 \\
\hline spline1 & 0.03107 & 0.7698 & -0.01246 & 0.8401 & -0.04385 & 0.3167 & -0.04083 & 0.2357 & -0.03696 & 0.1979 & -0.02610 & 0.2969 \\
\hline spline2 & 0.01770 & 0.3611 & 0.02632 & 0.2276 & 0.04751 & 0.0552 & 0.06459 & 0.0238 & 0.08677 & 0.0093 & 0.10328 & 0.0088 \\
\hline spline1_I & -0.17071 & 0.0345 & -0.12450 & 0.0181 & -0.10172 & 0.0093 & -0.08277 & 0.0082 & -0.06495 & 0.0140 & -0.05525 & 0.0171 \\
\hline spline2_I & -0.01314 & 0.4694 & -0.00431 & 0.8347 & 0.00667 & 0.7767 & 0.01485 & 0.5829 & 0.01686 & 0.5932 & 0.02035 & 0.5863 \\
\hline Boardsize & 0.08101 & 0.6478 & 0.08605 & 0.6271 & 0.09625 & 0.5860 & 0.09337 & 0.5965 & 0.08425 & 0.6324 & 0.07660 & 0.6637 \\
\hline pind_dir_1 & -0.00557 & 0.0464 & -0.00539 & 0.0536 & -0.00513 & 0.065 & -0.00491 & 0.0770 & -0.00470 & 0.0902 & -0.00464 & 0.0945 \\
\hline pro_s & 0.00739 & 0.009 & 0.00753 & 0.0077 & 0.00758 & 0.0072 & 0.00760 & 0.0070 & 0.00769 & 0.0063 & 0.00766 & 0.0065 \\
\hline fii_s & 0.05921 & $<.0001$ & 0.05975 & $<.0001$ & 0.06042 & $<.0001$ & 0.06083 & $<.0001$ & 0.06060 & $<.0001$ & 0.05976 & $<.0001$ \\
\hline ret_as1 & 0.01865 & 0.0025 & 0.01838 & 0.003 & 0.01787 & 0.0038 & 0.01760 & 0.0042 & 0.01746 & 0.0045 & 0.01771 & 0.0040 \\
\hline Rdint & 0.06300 & 0.1894 & 0.06275 & 0.1909 & 0.06165 & 0.1976 & 0.06235 & 0.1919 & 0.06452 & 0.1767 & 0.06717 & 0.1602 \\
\hline Advint & 0.07861 & $<.0001$ & 0.07949 & $<.0001$ & 0.08095 & $<.0001$ & 0.08071 & $<.0001$ & 0.07980 & $<.0001$ & 0.07907 & $<.0001$ \\
\hline Size & 0.07296 & 0.185 & 0.07990 & 0.1481 & 0.08672 & 0.1163 & 0.08759 & 0.1120 & 0.08848 & 0.1083 & 0.08771 & 0.1116 \\
\hline Industry Dummy & Yes & & Yes & & Yes & & Yes & & Yes & & Yes & \\
\hline R-squared & 0.2963 & & 0.2973 & & 0.3011 & & 0.3029 & & 0.3038 & & 0.3029 & \\
\hline
\end{tabular}


Table 9: Regression of Alternative Measures of Firm Performance on Busyness, Board Structure, and Other Firm Characteristics

\begin{tabular}{lrrrrrr}
\hline & \multicolumn{2}{c}{ Column A } & \multicolumn{2}{c}{ Column B } & \multicolumn{2}{c}{ Column C } \\
\hline & \multicolumn{2}{c}{ Q-ratio } & \multicolumn{2}{c}{ Return-to assets } & Net Value Added to Assets \\
& Estimate & P-Value & Estimate & P-Value & Estimate & P-Value \\
& & & & & & \\
& 0.25435 & 0.2723 & -0.24430 & 0.9503 & 16.83406 & 0.0011 \\
Intercept & -0.03054 & 0.1151 & -0.26841 & 0.4122 & -0.30610 & 0.4763 \\
spline1 & 0.01460 & 0.1821 & 0.49019 & 0.0078 & 0.89320 & 0.0002 \\
spline2 & -0.01685 & 0.0080 & -0.12716 & 0.2346 & -0.22930 & 0.1028 \\
tldirsp_ins_med & -0.03003 & 0.7002 & 0.53500 & 0.6851 & 1.42477 & 0.4109 \\
boardsize & -0.00130 & 0.2904 & -0.00679 & 0.7432 & 0.00101 & 0.9705 \\
pind_dir_1 & 0.00137 & 0.2701 & 0.08451 & $<.0001$ & 0.10941 & $<.0001$ \\
pro_s & 0.02992 & $<.0001$ & 0.35004 & $<.0001$ & 0.58892 & $<.0001$ \\
fii_s & 0.02077 & $<.0001$ & & & & \\
ret_as1 & 0.02888 & 0.1721 & 1.14113 & 0.0013 & 1.82575 & $<.0001$ \\
Rdint & 0.03616 & $<.0001$ & 0.26835 & 0.0195 & 0.75074 & $<.0001$ \\
Advint & 0.06759 & 0.0055 & 0.33785 & 0.4101 & -1.71138 & 0.0016 \\
Size & & & & & & \\
& Yes & & Yes & & 0.3011 & \\
Industry Dummy & 0.4041 & & 0.2973 & & & \\
R-squared & & & & & &
\end{tabular}


Table 10: Regression of Market to Book Ratio on Busyness, Board Structure, and Other firm Characteristics

- Group Effects

\begin{tabular}{|c|c|c|c|c|c|c|c|c|}
\hline & \multicolumn{2}{|c|}{ Column A } & \multicolumn{2}{|c|}{ Column B } & \multicolumn{2}{|c|}{ Column C } & \multicolumn{2}{|c|}{ Column D } \\
\hline & \multicolumn{2}{|c|}{ MVBR } & \multicolumn{2}{|c|}{ Q-Ratio } & \multicolumn{2}{|c|}{ Return to Assets } & \multicolumn{2}{|c|}{$\begin{array}{l}\text { Net Value Added } \\
\text { to Assets }\end{array}$} \\
\hline & Estimate & P-Value & Estimate & P-Value & Estimate & P-Value & Estimate & P-Value \\
\hline Intercept & -0.16592 & 0.7520 & 0.21913 & 0.3448 & -0.62090 & 0.8741 & 15.30067 & 0.0031 \\
\hline spline1 & -0.01224 & 0.8065 & -0.01917 & 0.3853 & -0.16235 & 0.6635 & 0.26997 & 0.5811 \\
\hline spline2 & 0.08902 & 0.0107 & 0.03169 & 0.0395 & 0.85641 & 0.0009 & 0.96047 & 0.0045 \\
\hline spline1 x group & -0.0316 & 0.4107 & -0.01092 & 0.5194 & -0.03315 & 0.9079 & -0.77709 & 0.0391 \\
\hline spline2 x group & -0.08874 & 0.0604 & -0.03704 & 0.0758 & -0.77935 & 0.0265 & -0.27705 & 0.5465 \\
\hline tldirsp_ins_med & -0.02305 & 0.1164 & -0.01412 & 0.0296 & -0.08908 & 0.4156 & -0.13138 & 0.3600 \\
\hline boardsize & 0.07689 & 0.6626 & -0.03016 & 0.6983 & 0.46607 & 0.7231 & 1.61775 & 0.3485 \\
\hline pind_dir_1 & -0.00316 & 0.2631 & -0.00062 & 0.6154 & 0.00405 & 0.8476 & 0.01807 & 0.5134 \\
\hline pro_s & 0.00689 & 0.0145 & 0.00110 & 0.3747 & 0.07901 & 0.0001 & 0.10048 & 0.0002 \\
\hline fii_s & 0.05806 & $<.0001$ & 0.02939 & $<.0001$ & 0.33643 & $<.0001$ & 0.56693 & $<.0001$ \\
\hline ret_as1 & 0.01562 & 0.0116 & 0.01985 & $<.0001$ & & & & \\
\hline rdint & 0.06713 & 0.1595 & 0.03198 & 0.1291 & 1.17770 & 0.0009 & 1.86410 & $<.0001$ \\
\hline advint & 0.07956 & $<.0001$ & 0.03637 & $<.0001$ & 0.27364 & 0.0170 & 0.72957 & $<.0001$ \\
\hline size & 0.08514 & 0.1214 & 0.07125 & 0.0034 & 0.37675 & 0.3576 & -1.57510 & 0.0035 \\
\hline Industry Dummy & Yes & & Yes & & Yes & & Yes & \\
\hline R-Sqaured & 0.3083 & & 0.4131 & & 0.2293 & & 0.3601 & \\
\hline
\end{tabular}

